\title{
Pengolahan Limbah Pewarna Metilen Biru Menggunakan Arang Aktif dan Zeolit Aktif dengan Katalis Fe dan Oksidator Hidrogen Peroksida
}

\author{
Maryudi Maryudi ${ }^{*}$, Agus Aktawan1, Shinta Amelia1 \\ 1Program Studi Teknik Kimia, Fakultas Teknologi Industri, Universitas Ahmad Dahlan, DI Yogyakarta, \\ Indonesia
}

Corresponding Author: Maryudi

maryudi@che.uad.ac.id

Received: March 2021

Accepted: August 2021

Published: September 2021

CMaryudi et al. This is an open-access article distributed under the terms of the Creative Commons Attribution License, which permits unrestricted use, distribution, and reproduction in any medium, provided the original author and source are credited.

\begin{abstract}
The textile industry including batik has provided broad benefits to society from an economic standpoint. However, there is negative impact from wastewater generated in the production process, which is containing dyes. Various types of dyes are used in the coloring process, and methylene blue is one of most used dye. Various ways have been done to treat wastewater containing methylene blue. Methylene blue processing techniques by adsorption have been carried out with various types of adsorbents. Research on the comparison of the ability of commercial activated charcoal and commercial activated zeolite to adsorb methylene blue was carried out with the addition of an Fe catalyst and a hydrogen peroxide oxidizer. The results showed that the addition of Fe catalyst would increase the degradation of methylene blue in the waste either with activated charcoal or activated zeolite. The combination of using Fe catalyst and hydrogen peroxide oxidizer further increases the removal of methylene blue in both types of adsorbents, activated charcoal and activated zeolite. Activated zeolite has the better ability to adsorb methylene blue than activated charcoal under various conditions.
\end{abstract}

Keywords: adsorption, activated charcoal, activated zeolite, Fe, hydrogen peroxide

\section{Pendahuluan}

Industri batik selain memberikan dampak positif bagi perekonomian juga menyisakan dampak negatif bagi lingkungan karena limbah yang dihasilkan ${ }^{[1]}$. Industri batik dan tekstil merupakan salah satu penghasil limbah cair yang berasal dari pewarnaan dengan jumlah yang cukup besar sehingga dapat menimbulkan pencemaran lingkungan. Pengolahan air limbah batik mutlak dilakukan agar menghindari pencemaran lingkungan[2][3].

Metilen biru merupakan zat warna dasar yang penting dalam proses pewarnaan kulit, kain mori, dan kain katun ${ }^{[4][5]}$. Metilen biru dapat menyebabkan beberapa efek yang merugikan. Apabila terkena paparan metilen biru secara akut dapat meningkatkan detak jantung, muntah, shock, pembentukan heinz body, cyanosis, jaundice, quadriplegia dan jaringan nekrosis pada manusia ${ }^{[6][7]}$. Beberapa efek tersebut merupakan alasan yang menyebabkan pentingnya menghilangkan metilen biru dari perairan.

Beberapa cara mengolah limbah yaitu dengan cara filtrasi, flokulasi, penghilangan warna (dekolorisasi), dan adsorpsi[7]. Di antara cara tersebut, adsorpsi merupakan teknik mengolah limbah yang paling umum dan sering 
digunakan karena biayanya murah, metodenya sederhana, mudah dilakukan, dan cocok untuk zat yang beracun. Adsorpsi merupakan alternatif terbaik untuk mengatasi pencemaran zat warna ${ }^{[8][9]}$. Adsorben yang umum digunakan adalah karbon aktif/arang aktif, silika gel, alumina, zeolit, dan penyaring molekul.

Teknologi advanced oxidation processes (AOP) merupakan teknologi alternatif pengolahan limbah cair yang cukup ekonomis karena mampu menghemat tempat dan energi, biaya investasi murah, aman, sederhana, proses pengolahannya cepat dan cukup efektif. Kelebihan metode ini adalah dapat mendegradasi senyawa-senyawa berbahaya yang bersifat non-biodegradable dalam limbah melalui proses oksidasi ${ }^{[10]}$. Pada teknologi AOP melibatkan kombinasi dari proses fotokimia dan katalisis yang terintegrasi untuk dapat melangsungkan suatu reaksi transformasi kimia. Reaksi transformasi tersebut berlangsung pada permukaan bahan katalis semikonduktor yang terinduksi oleh sinar. Beberapa jenis semikonduktor yang dapat dipakai untuk proses fotokatalisis dari kelompok oksida misalnya $\mathrm{TiO}_{2}, \mathrm{Fe}_{2} \mathrm{O}_{3}, \mathrm{ZnO}, \mathrm{WO}_{3}$, atau $\mathrm{SnO}_{2}$. Sedangkan dari kelompok sulfida adalah CdS, ZnS, CuS, FeS, dan lain-lain[11]-[14]. Arang aktif dihasilkan dari berbagai biomassa melalui proses karbonisasi $500{ }^{\circ} \mathrm{C}$ dan tahap selanjutnya dilakukan aktivasi pada suhu $800-900{ }^{\circ} \mathrm{C}$. Arang aktif bisa digunakan adsorben dan juga media pendegradasi sumber pencemar seperti residu pestisida dan logam berat tertentu ${ }^{[15]}$.

Selain arang aktif, terdapat zeolit yang merupakan katalis yang unik, karena memiliki ukuran pori yang sangat kecil dan seragam jika dibandingkan dengan karbon aktif. Zeolit dapat berfungsi sebagai penyerap gas atau cairan[16],[17]. Zeolit dikenal sebagai adsorben yang selektif dan mempunyai efektifitas adsorpsi yang tinggi[18],[19]. Kombinasi proses dengan melibatkan proses oksidasi dengan oksidator kuat seperti campuran hidrogen peroksida dengan sinar ultraviolet $\left(\mathrm{H}_{2} \mathrm{O}_{2}+\mathrm{UV}\right)$ atau advanced oxidation process (AOP) telah digunakan untuk mengoksidasi polutan-polutan zat warna dalam air limbah ${ }^{[20]}$. Penggunaan $\mathrm{H}_{2} \mathrm{O}_{2}$ mempunyai keuntungan, yaitu: aman, selektif, kuat dan mudah diperoleh. Pada umumnya, beberapa parameter AOPs yang biasa berpengaruh terhadap hasil pengolahan limbah diantaranya $\mathrm{pH}$ dan waktu kontak[21][22]. Keunggulan metode AOPs antara lain mampu mendegradasi polutan organik yang tidak terdegradasi dengan proses konvensional, dapat mereduksi zat warna yang tidak bisa diuraikan dengan teknologi lain[23]. Metode AOP telah digunakan untuk melakukan pengolahan air limbah yang mengandung zat warna, seperti direct red dan direct blue [24],[25].

Naskah ini melaporkan hasil perbandingan penggunaan arang aktif dan zeolit dalam mendegradasi zat warna metilen biru dengan bantuan katalis Fe dan zat oksidator $\mathrm{H}_{2} \mathrm{O}_{2}$.

\section{Metodologi Penelitian}

\section{Bahan kimia}

Bahan yang digunakan adalah arang aktif komersial dari UD. Bratachem, zeolit aktif komersial dari UD. Bratachem, $\mathrm{Fe}\left(\mathrm{NO}_{3}\right)_{3} .9 \mathrm{H}_{2} \mathrm{O}$ (Merck), zat warna metilen biru, akuades dan $\mathrm{H}_{2} \mathrm{O}_{2}$.

\section{Peralatan}

Alat yang digunakan adalah beaker glass, Erlenmeyer, pipet dan pengaduk berupa magnetic stirrer. Analisis kadar metilen biru dilakukan spektrofotometer UV-Vis.

\section{Prosedur penelitian}

\section{Persiapan bahan}

Penyiapan arang aktif dan zeolit dilakukan dengan menghaluskan masing-masing bahan dan diayak dengan ukuran 40 mesh. Uji BET dilakukan untuk mengetahui luas muka arang aktif dan zeolit. Arang aktif dan zeolit sebagian dilakukan treatment dengan katalis Fe 4\%. Arang aktif dan zeolit dimasukkan ke dalam $\mathrm{Fe}\left(\mathrm{NO}_{3}\right)_{3} .9 \mathrm{H}_{2} \mathrm{O}$ sebanyak $4 \%$ yang telah di larutkan dengan isopropyl alkohol kemudian diaduk dengan ultrasonikator selama 1 jam. Larutan metilen biru disiapkan dalam konsentrasi 25 dan 45 ppm dengan melarutkan metilen biru dalam akuades di dalam beaker glass dan diaduk sampai homogen. 


\section{Proses adsorpsi}

Proses adsorpsi larutan metilen biru dilakukan dengan tiga kondisi adsorben berbeda, yaitu arang aktif dan zeolit, arang aktif dan zeolit dengan perendaman $\mathrm{Fe} 4 \%$, dan arang aktif dan zeolit dengan perendaman $\mathrm{Fe} 4 \%$ ditambah $\mathrm{H}_{2} \mathrm{O}_{2}$. Adsorpsi metilen biru dilakukan dengan menambahkan $25 \mathrm{mg}$ adsorben ke dalam $200 \mathrm{ml}$ larutan metilen biru 25 ppm di dalam Erlenmeyer $500 \mathrm{ml}$ dan diaduk dengan magnetic stirrer dengan kecepatan $200 \mathrm{rpm}$. Sampel sebanyak $2 \mathrm{ml}$ diambil pada waktu 5, 15, 30, 60, 90, 120 dan 180 menit. Percobaan diulang untuk konsentrasi metilen biru $45 \mathrm{ppm}$. Selanjutnya percobaan diulang untuk adsorben dengan perendaman $\mathrm{Fe}$ dan ditambah $\mathrm{H}_{2} \mathrm{O}_{2}$.

\section{Pengukuran}

Analisis kandungan metilen biru dilakukan spektrofotometer UV-Vis pada panjang gelombang $663 \mathrm{~nm}$.

\section{Hasil dan Diskusi}

\section{Karakteristik arang aktif dan zeolit}

Hasil uji BET terhadap arang aktif dan zeolit ditampilkan pada Tabel 1. Data menunjukkan bahwa zeolit memiliki luas muka spesifik yang lebih besar dibandingkan dengan arang aktif. Volume pori spesifik zeolit juga diperoleh hasil yang lebih besar dibanding arang aktif.

\section{Pengaruh konsentrasi metilen biru}

Data konsentrasi metilen biru pada berbagai waktu, ditampilkan pada Gambar 1 dan Gambar 2. Konsentrasi metilen biru semakin menurun dengan semakin lama kontak. Pada awal kontak penurunan berjalan cepat, namun semakin lama penurunan konsentrasi semakin lambat. Gambar 2 menunjukkan persen removal metilen biru. Perbedaan konsentrasi metilen biru 25 dan 45 ppm menunjukkan bahwa pada konsentrasi $45 \mathrm{ppm}$ persen removal lebih rendah dibanding pada 25 ppm, karena katalis sudah mulai jenuh.

Penurunan kadar zat warna metilen biru dikarenakan adanya reaksi karbon aktif yang mempunyai pori-pori untuk mengikat zat warna metilen biru. Semakin panjang waktu kontak antara karbon aktif dengan limbah zat warna metilen biru, maka daya serap polutan metilen biru semakin banyak yang mengakibatkan pemutusan ikatan kimia metilen biru secara terus menerus yang mampu memudarkan warna metilen biru menjadi jernih ${ }^{[23]}$.

Pada penelitian sebelumnya ${ }^{[26]}$ dilaporkan bahwa persentase removal zat adsorbat terlihat meningkat tajam dari waktu kontak 5 hingga 15 menit dan mencapai kesetimbangan maksimal dalam waktu 60 menit. Penambahan waktu kontak setelah kondisi optimum justru menyebabkan sebagian molekul zat warna terlepas akibat lamanya waktu kontak ${ }^{27]}$.

Penurunan kadar metilen biru meningkat seiring dengan peningkatan lama penyinaran sinar matahari dan sinar UV. Pada penyinaran selama 5-50 menit terjadi peningkatan penurunan kadar yang cukup besar, sedangkan pada menit ke 50-120 penurunan kadar yang diperoleh cenderung konstan. Hal ini disebabkan semakin lama penyinaran warna larutan menjadi pudar, sehingga untuk mencapai fotokatalis menjadi lebih mudah ${ }^{[28]}$.

Tabel 1. Hasil uji BET zeolit dan arang aktif

\begin{tabular}{lcc}
\hline \multicolumn{1}{c}{ Parameter } & Arang aktif & Zeolit \\
\hline Luas muka, $\mathrm{m}^{2} /$ gram & 40.533 & 53.780 \\
Volume pori total, $\mathrm{cm}^{3} /$ gram & 0.081 & 0.161 \\
Diameter pori, $\mathrm{nm}$ & 3.597 & 3.599
\end{tabular}




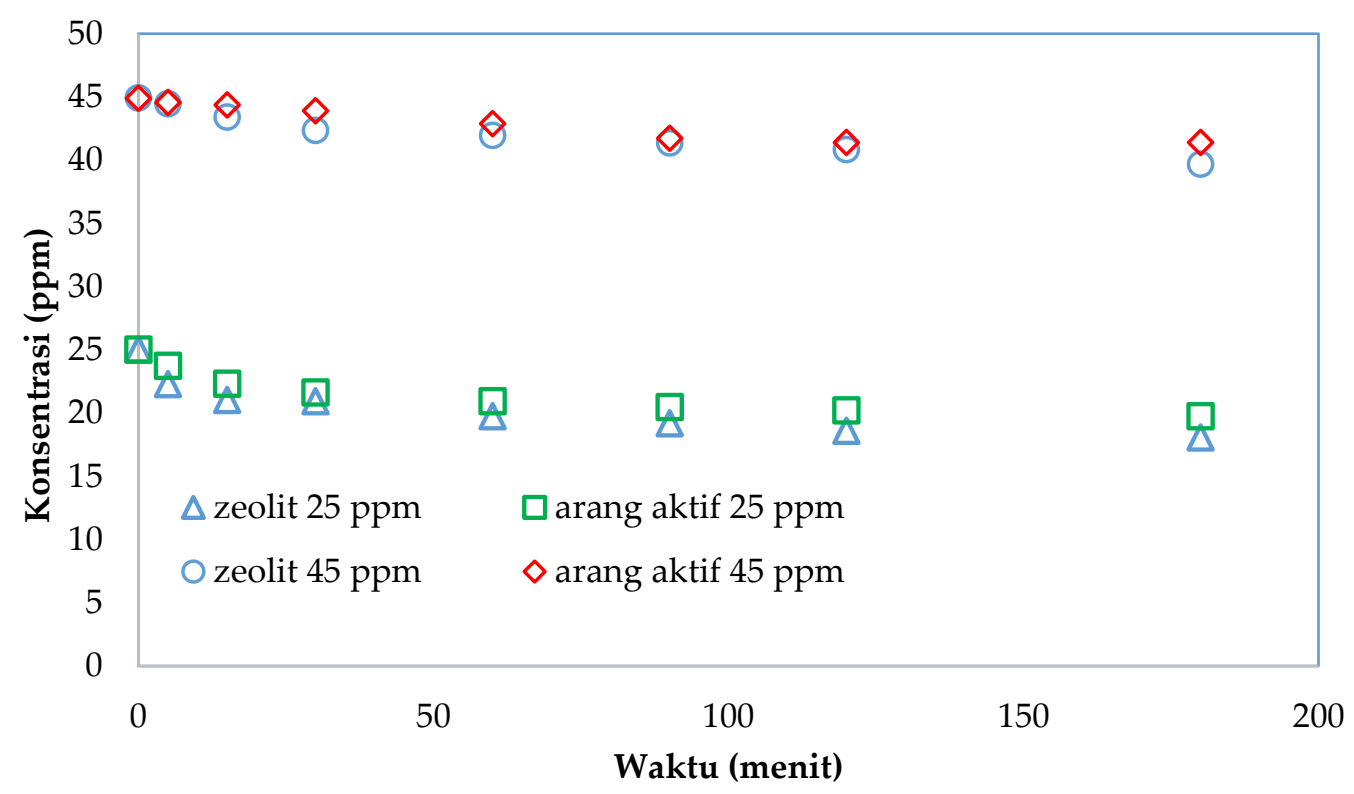

Gambar 1. Konsentrasi metilen biru pada berbagai waktu.

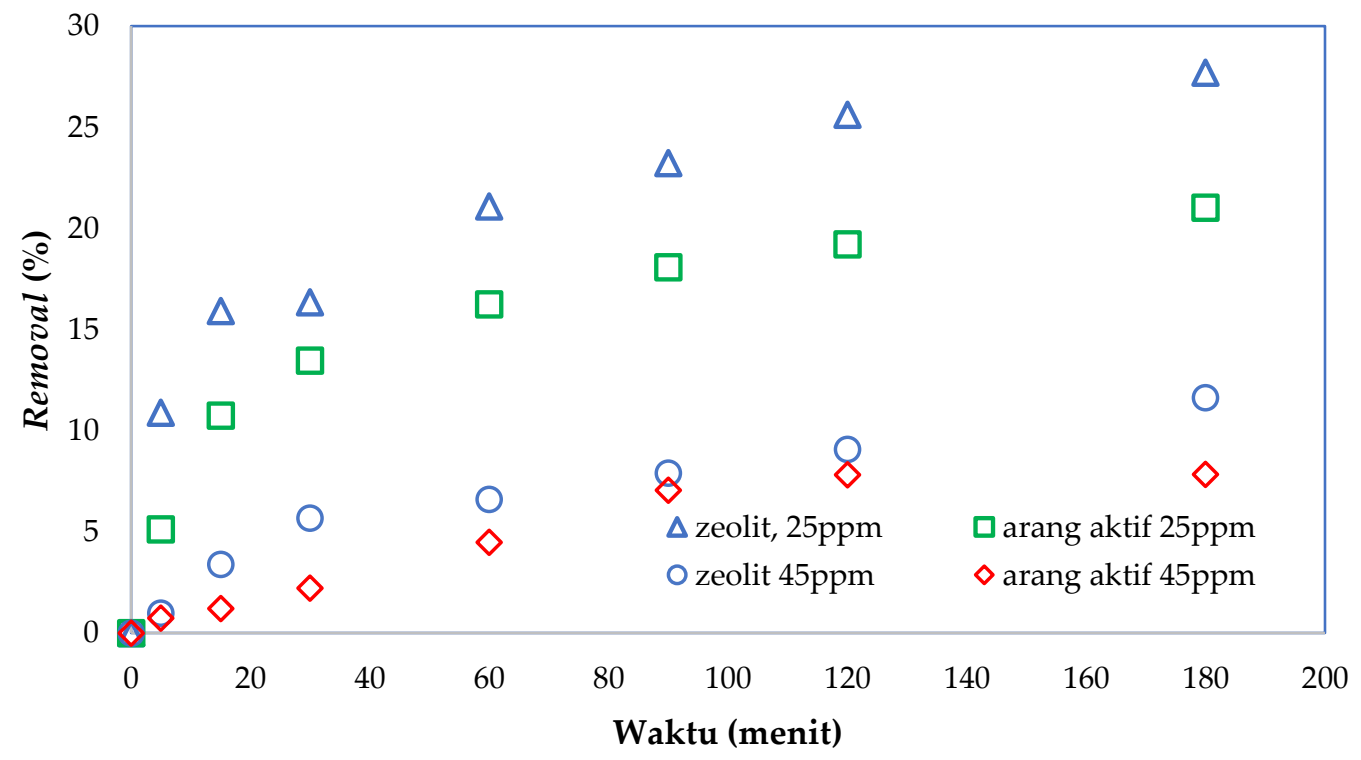

Gambar 2. Removal metilen biru pada berbagai waktu.

\section{Pengaruh katalis pada adsorpsi}

Penggunaan katalis pada adsorpsi metilen biru dilakukan menggunakan $\mathrm{Fe} 4 \%$ dan $\mathrm{H}_{2} \mathrm{O}_{2}$ (metode AOP). Data konsentrasi metilen biru ditunjukkan pada Gambar 3 dan Gambar 4. Perbandingan penurunan konsentrasi metilen biru dengan karbon aktif, karbon aktif dengan
$\mathrm{Fe}$, dan karbon aktif dengan Fe dan kombinasi metode AOP dapat dilihat pada Gambar 4. Penurunan konsentrasi larutan metilen biru pada konsentrasi 25 ppm dengan menggunakan katalis Fe dan dikombinasi dengan metode AOP lebih baik dibandingkan tanpa katalis Fe dan tanpa menggunakan metode AOP. Hal ini 
terjadi karena penambahan Fe pada arang aktif dan zeolit aktif menaikan aktivitas fotokatalitik dalam mereduksi metilen biru pada daerah kerja UV, yang disebabkan terjadinya kombinasi proses adsorpsi ${ }^{[29]}$. Penambahan oksidator kuat hidrogen peroksida akan menyebabkan peningkatan tingkat penurunan kadar metilen biru ${ }^{[20]}$. Hidrogen peroksida $\left(\mathrm{H}_{2} \mathrm{O}_{2}\right)$ diketahui dapat mengalami pemecahan menjadi dua radikal $\mathrm{OH}$ apabila ditambahkan ke dalam suatu larutan berair atau air limbah. Hal ini disebabkan oleh kenyataan bahwa tanpa adanya sinar UV, hanya sebagian kecil $\left(\mathrm{H}_{2} \mathrm{O}_{2}\right)$ yang dapat mengalami pemecahan menjadi radikal $\mathrm{OH}^{[17]}$.

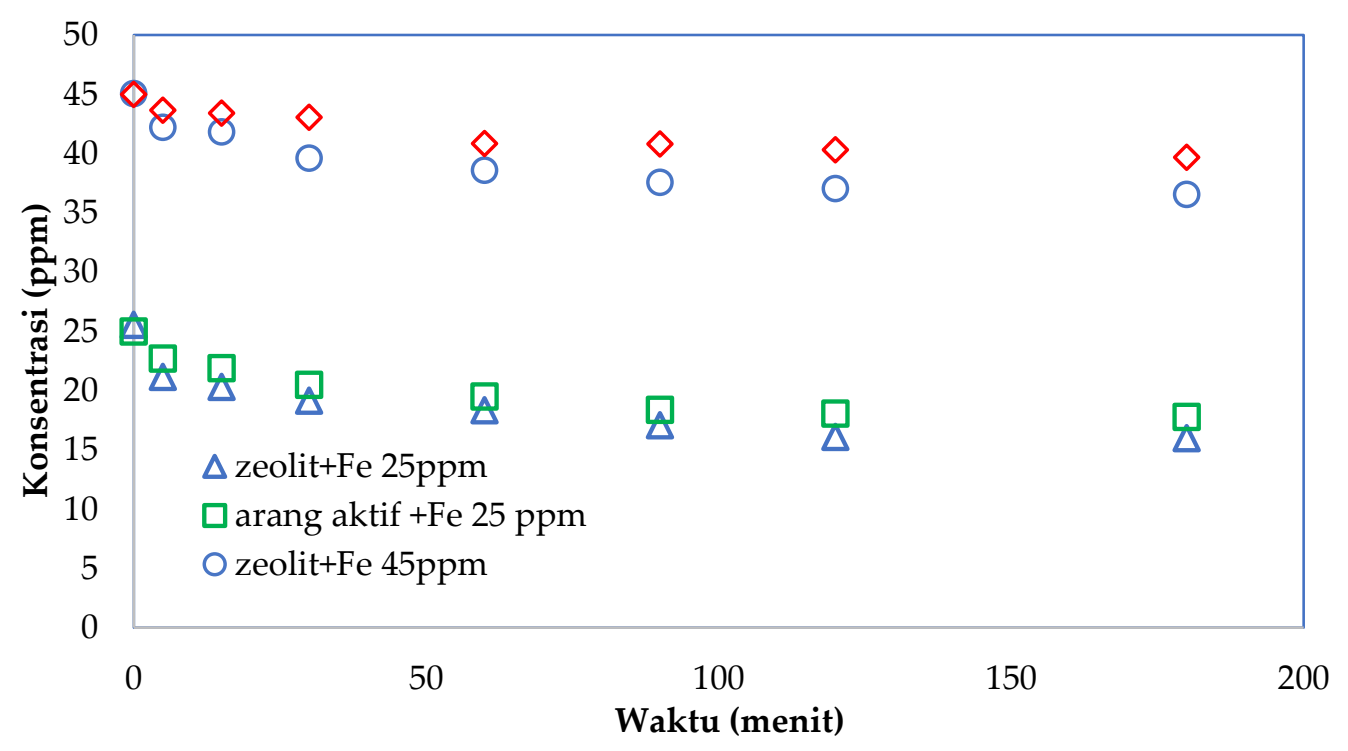

Gambar 3. Hubungan konsentrasi metilen biru pada berbagai waktu dengan penambahan katalis Fe.

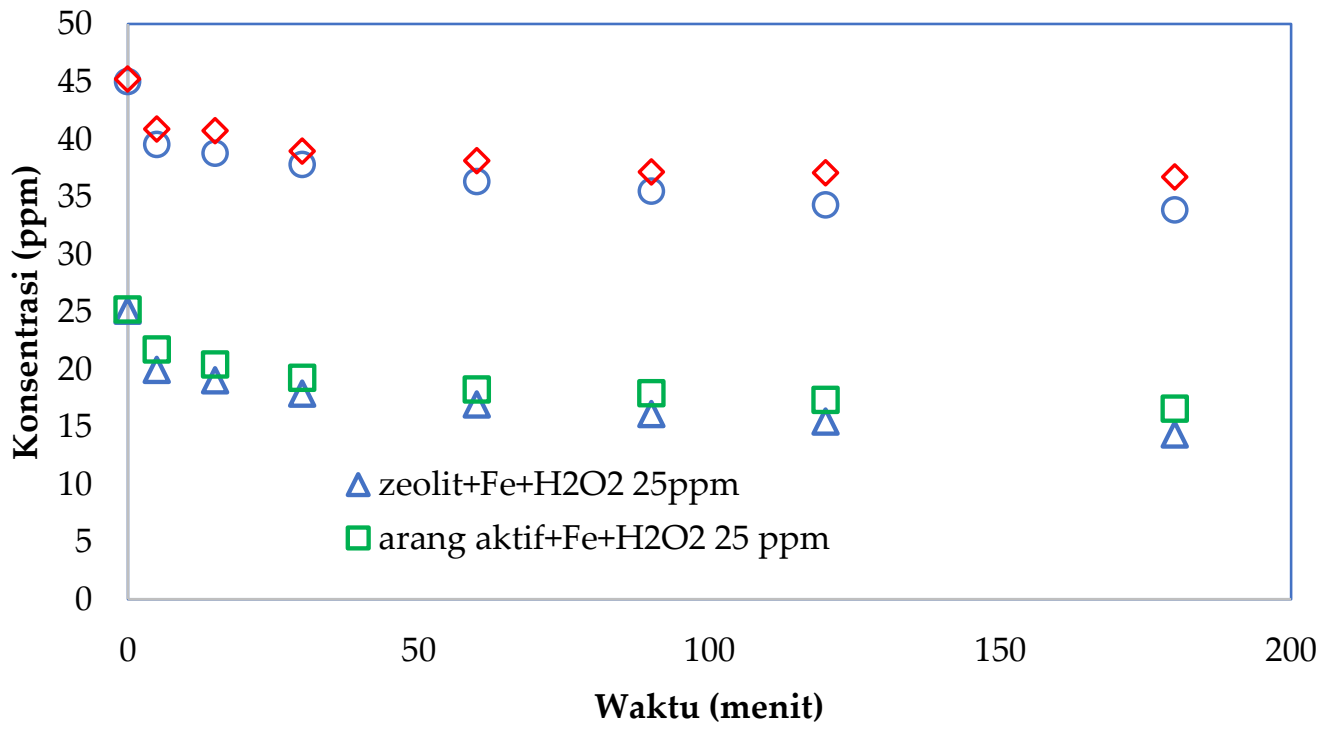

Gambar 4. Hubungan konsentrasi pada berbagai waktu dengan penambahan katalis Fe dan oksidator $\mathrm{H}_{2} \mathrm{O}_{2}$. 
Pengaruh penggunaan katalis $\mathrm{Fe}$ dan penambahan oksidator $\mathrm{H}_{2} \mathrm{O}_{2}$ pada arang aktif dan zeolit dapat dilihat pada Gambar 5 dan Gambar 6. Secara umum penambahan Fe akan meningkatkan kemampuan adsorpsi arang aktif maupun zeolit aktif. Penambahan $\mathrm{H}_{2} \mathrm{O}_{2}$ akan lebih meningkatkan tingkat degradasi limbah metilen biru, baik untuk arang aktif maupun zeolit aktif. Hasil ini sejalan dengan hasil penggunaan $\mathrm{H}_{2} \mathrm{O}_{2}$ pada pengolahan limbah yang mengandung pewarna direct red 23 metode AOP[24].

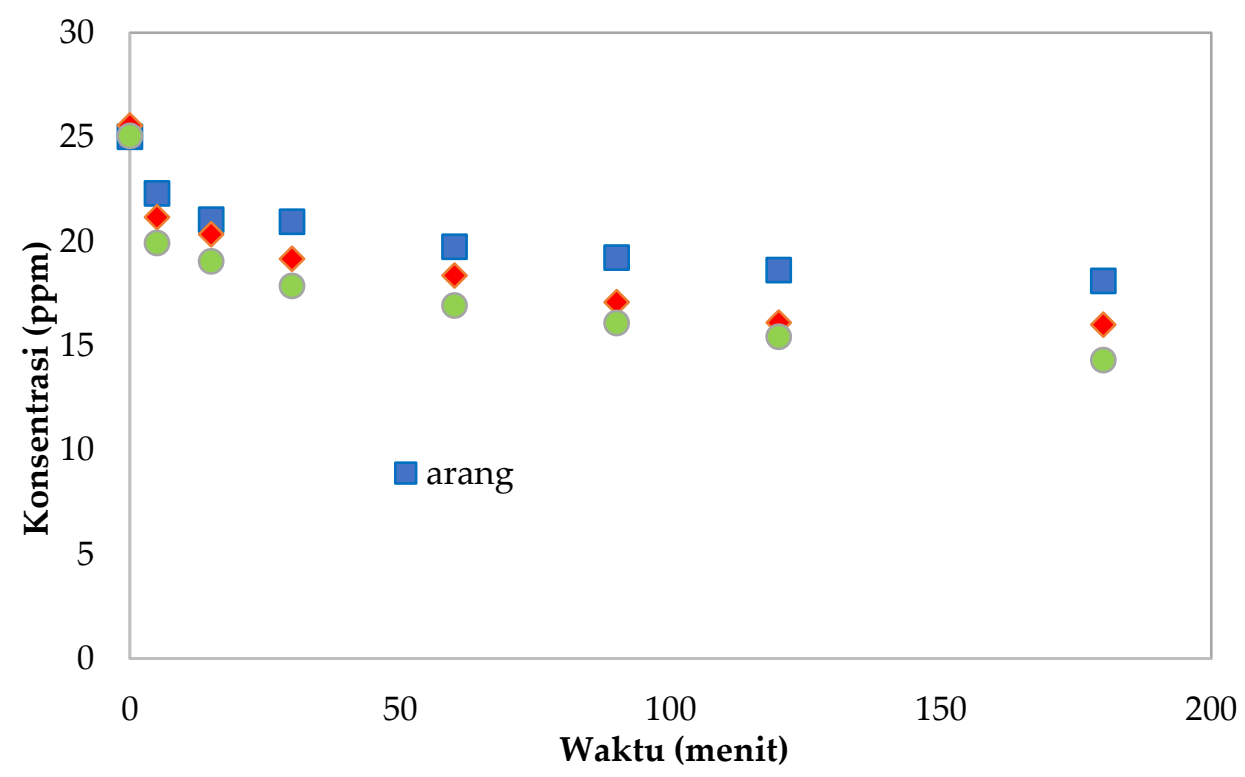

Gambar 5. Hubungan konsentrasi pada berbagai waktu dengan adsorben arang aktif dan penambahan katalis Fe dan oksidator $\mathrm{H}_{2} \mathrm{O}_{2}$ pada konsentrasi metilen biru 25 ppm.

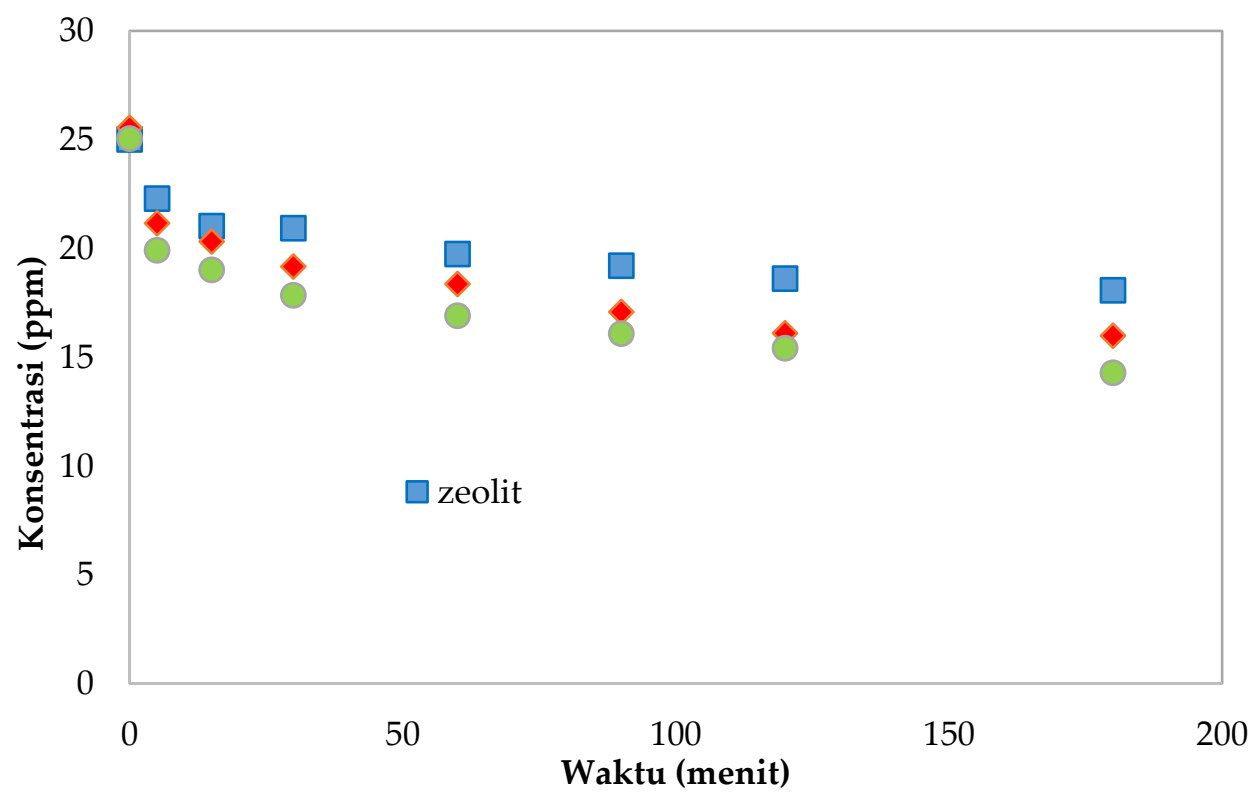

Gambar 6. Hubungan konsentrasi pada berbagai waktu dengan adsorben zeolit aktif, zeolit aktif dengan penambahan katalis $\mathrm{Fe}$ dan $\mathrm{H}_{2} \mathrm{O}_{2}$ pada konsentrasi metilen biru 25 ppm. 


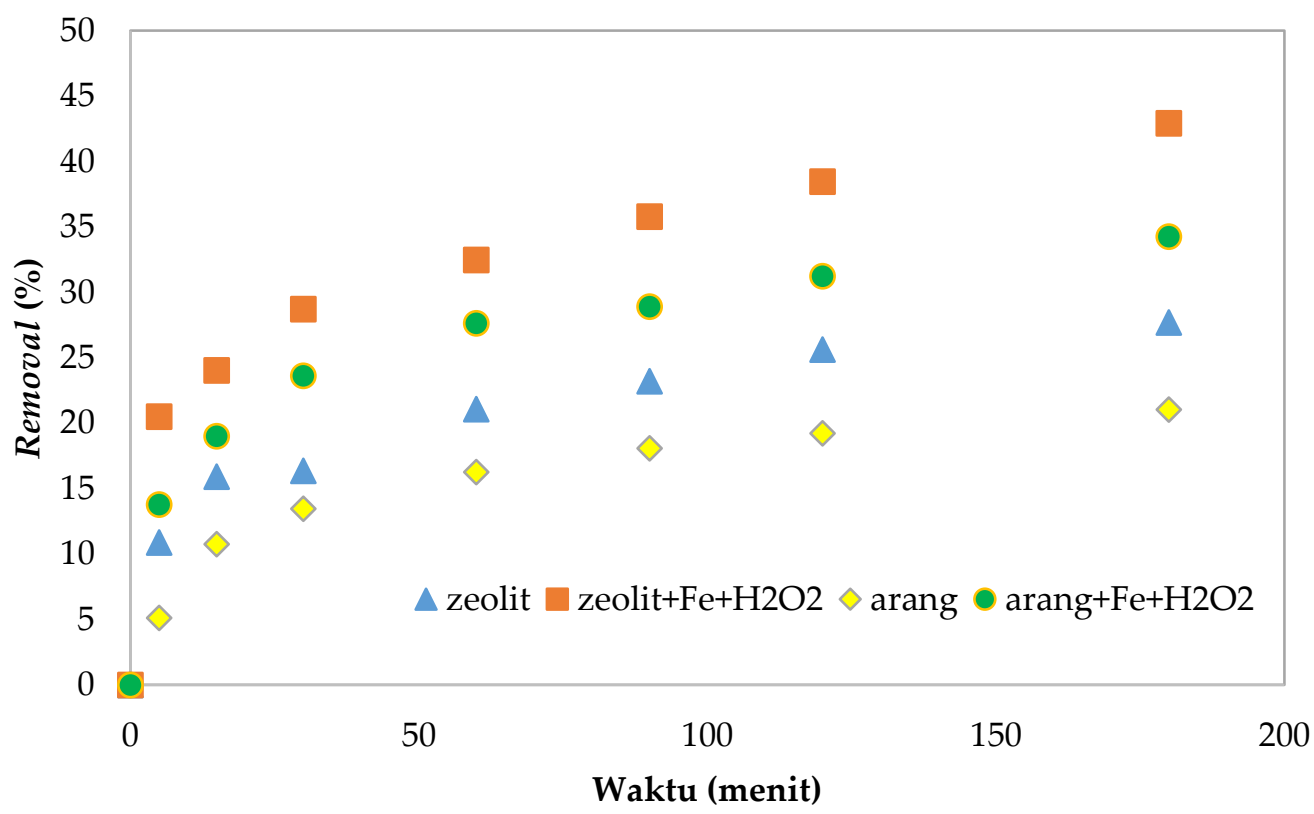

Gambar 7. Perbandingan removal metilen biru dengan adsorben zeolit dan arang baik dengan dan tanpa penambahan katalis Fe dan $\mathrm{H}_{2} \mathrm{O}_{2}$.

\section{Perbandingan kemampuan adsorpsi arang} aktif dan zeolit aktif

Removal terhadap metilen biru oleh adsorben arang aktif dan zeolit aktif pada konsentrasi 25 ppm ditunjukkan pada Gambar 7. Hasil menunjukkan perbandingan kemampuan adsorpsi antara arang dan zeolit aktif, baik dengan maupun tanpa katalis Fe dan oksidator $\mathrm{H}_{2} \mathrm{O}_{2}$. Zeolit aktif dengan katalis $\mathrm{Fe}$ menunjukkan kinerja yang lebih baik dibanding dengan arang aktif. Hasil ini didukung dengan data luas muka dan volume pori total zeolit aktif yang lebih besar dibanding dengan arang aktif (Tabel 1), sehingga mampu menyerap adsorbat lebih banyak.

\section{Kesimpulan}

Adsorpsi metilen biru dengan arang aktif dan zeolit aktif telah dilakukan dengan kondisi tanpa maupun dengan aktivasi $\mathrm{Fe}$ dan dengan penambahan hidrogen peroksida. Hasil menunjukkan bahwa penambahan katalis $\mathrm{Fe}$ meningkatkan penurunan kadar metilen biru. Penambahan oksidator hidrogen peroksida semakin meningkatkan penurunan kadar metilen biru baik pada adsorben arang aktif maupun zeolit aktif. Kemampuan penyerapan metilen biru oleh zeolit aktif lebih baik dibanding dengan arang aktif.

\section{Ucapan Terima Kasih}

Penulis mengucapkan terima kasih atas bantuan dana penelitian melalui Skema Dana Penelitian Internal melalui Lembaga Penelitian dan Pengabdian Masyarakat Universitas Ahmad Dahlan Yogyakarta dengan nomor kontrak: PD235/SP3/LPPM-UAD/2020.

\section{Daftar Pustaka}

1. Mozammel, H. M., Masahiro, O. \& Bhattacharya, S. C., Activated charcoal from coconut shell using $\mathrm{ZnCl} 2$ activation. Biomass and Bioenergy, 22(5): 397-400 (2002).

2. Mukimin, A., Zen, N., Purwanto, A., Wicaksono, K. A., Vistanty, H. \& Alfauzi, A. S., Application of a full-scale electrocatalytic reactor as real batik printing 
wastewater treatment by indirect oxidation process. J. Environ. Chem. Eng., 5(5): 52225232 (2017).

3. Rashidi, H. R., Sulaiman, N. M. N. \& Hashim, N. A., Batik industry synthetic wastewater treatment using nanofiltration membrane. Procedia Eng., 44: 2010-2012 (2012).

4. Hameed, B. H. \& Ahmad, A. A., Batch adsorption of methylene blue from aqueous solution by garlic peel, an agricultural waste biomass. J. Hazard. Mater., 164(2-3): 870-875 (2009).

5. Hamdaoui, O. \& Chiha, M., Removal of methylene blue from aqueous solutions by wheat bran. Acta Chim. Slov., 54(2): 407-418 (2007).

6. Kumar, P. S., Ramalingam, S. \& Sathishkumar, K., Removal of methylene blue dye from aqueous solution by activated carbon prepared from cashew nut shell as a new low-cost adsorbent. Korean J. Chem. Eng., 28(1): 149-155 (2011).

7. Gürses, A., Karaca, S., Doğar, Ç., Bayrak, R., Açikyildiz, M. \& Yalçin, M., Determination of adsorptive properties of clay/water system: methylene blue sorption. J. Colloid Interface Sci., 269(2): 310-314 (2004).

8. Chowdhury, S., Mishra, R., Saha, P. \& Kushwaha, P., Adsorption thermodynamics, kinetics and isosteric heat of adsorption of malachite green onto chemically modified rice husk. Desalination, 265(1-3): 159-168 (2011).

9. Saha, P., Chowdhury, S., Gupta, S. \& Kumar, I., Insight into adsorption equilibrium, kinetics and thermodynamics of malachite green onto clayey soil of Indian origin. Chem. Eng. J., 165(3): 874-882 (2010).

10. Malato, S., Blanco, J., Cáceres, J., FernándezAlba, A. R., Agüera, A. \& Rodríguez, A., Photocatalytic treatment of water-soluble pesticides by photo-Fenton and $\mathrm{TiO} 2$ using solar energy. Catal. Today, 76(2-4): 209-220 (2002).

11. Wu, Q., Zhao, J., Qin, G., Wang, C., Tong, X. \& Xue, S., Photocatalytic reduction of
$\mathrm{Cr}(\mathrm{VI})$ with $\mathrm{TiO} 2$ film under visible light. Appl. Catal. B Environ., 142: 142-148 (2013).

12. Babu, D. S., Srivastava, V., Nidheesh, P. V. \& Kumar, M. S., Detoxification of water and wastewater by advanced oxidation processes. Sci. Total Environ., 696: 133961 (2019).

13. Arzate, S., Pfister, S., Oberschelp, C. \& Sánchez-Pérez, J. A., Environmental impacts of an advanced oxidation process as tertiary treatment in a wastewater treatment plant. Sci. Total Environ., 694: 133572 (2019).

14. Poblete, R., Cortes, E., Bakit, J. \& LunaGaliano, Y., Landfill leachate treatment using combined fish scales based activated carbon and solar advanced oxidation processes. Process Saf. Environ. Prot., 123: 253-262 (2019).

15. Cao, Y., Wang, K., Wang, X., Gu, Z., Ambrico, T., Gibbons, W., Fan, Q., et al., Preparation of active carbons from corn stalk for butanol vapor adsorption. J. Energy Chem., 26(1): 35-41 (2017).

16. Chmielewská, E., Natural zeolite: Alternative adsorbent in purification or post-treatment of waters. in Modified Clay and Zeolite Nanocomposite Materials, (eds. Mercurio, M., Sarkar, B. \& Langella, A.), Elsevier, 87-112 (2019).

17. Moideen, S. N. F., Din, M. F. M., Rezania, S., Ponraj, M., Rahman, A. A., Pei, L. W., Ismail, Z., et al., Dual phase role of composite adsorbents made from cockleshell and natural zeolite in treating river water. J. King Saud Univ. - Sci., 32(1): 1-6 (2020).

18. Wang, S. \& Peng, Y., Natural zeolites as effective adsorbents in water and wastewater treatment. Chem. Eng. J., 156(1): 11-24 (2010).

19. Hor, K. Y., Chee, J. M. C., Chong, M. N., Jin, B., Saint, C., Poh, P. E. \& Aryal, R., Evaluation of physicochemical methods in enhancing the adsorption performance of natural zeolite as low-cost adsorbent of methylene blue dye from wastewater. J. Clean. Prod., 118: 197-209 (2016). 
20. Glaze, W. H., Kang, J. W. \& Chapin, D. H., The chemistry of water treatment processes involving ozone, hydrogen peroxide and ultraviolet radiation. Ozone Sci. Eng., 9(4): 335-352 (1987).

21. Rueda-Márquez, J. J., Pintado-Herrera, M. G., Martín-Díaz, M. L., Acevedo-Merino, A. \& Manzano, M. A., Combined AOPs for potential wastewater reuse or safe discharge based on multi-barrier treatment (microfiltration-H2O2/UV-catalytic wet peroxide oxidation). Chem. Eng. J., 270: 8090 (2015).

22. Zhou, J., Liu, P., Liu, Z., Zhang, J. \& Huang, $X$., Simultaneous recovery of phosphorus with nickel purification in nickel-plating wastewater via $\mathrm{Fe} / \mathrm{C}$ activated $\mathrm{H} 2 \mathrm{O} 2$ oxidation. Chem. Eng. J., 381: 122702 (2020).

23. Muruganandham, M. \& Swaminathan, M., Advanced oxidative decolourisation of Reactive Yellow 14 azo dye by UV/TiO2, $\mathrm{UV} / \mathrm{H} 2 \mathrm{O} 2, \quad \mathrm{UV} / \mathrm{H} 2 \mathrm{O} 2 / \mathrm{Fe} 2+$ processes-a comparative study. Sep. Purif. Technol., 48(3): 297-303 (2006).

24. Hassaan, M. A., El Nemr, A., El-Zahhar, A. A., Idris, A. M., Alghamdi, M. M., Sahlabji, T. \& Said, T. O., Degradation mechanism of Direct Red 23 dye by advanced oxidation processes: a comparative study. Toxin Rev.,
$1-10(2020)$.

25. Hassaan, M. A., El Nemr, A. \& Madkour, F. F., Testing the advanced oxidation processes on the degradation of Direct Blue 86 dye in wastewater. Egypt. J. Aquat. Res., 43(1): 11-19 (2017).

26. Ilomuanya, M. O., Nashiru, B., Ifudu, N. D. \& Igwilo, C. I., Effect of pore size and morphology of activated charcoal prepared from midribs of Elaeis guineensis on adsorption of poisons using metronidazole and Escherichia coli $\mathrm{O} 157: \mathrm{H7}$ as a case study. J. Microsc. Ultrastruct., 5(1): 32-38 (2017).

27. Bansal, R. C. \& Goyal, M., Activated carbon adsorption. CRC Press, (2005).

28. Amelia, S., Rahmadani, W., Amalia, L. R. \& Mufrodi, Z., Degradation of surfactant waste of leather tanning using Fe2O3/activated carbon catalyst. Maj. Kulit, Karet, dan Plast., 35(2): 49-54 (2020).

29. Amelia, S., Sediawan, W. B., Mufrodi, Z. \& Ariyanto, T., Modification of iron oxide catalysts supported on the biomass based activated carbon for degradation of dye wastewater. J. Bahan Alam Terbarukan, 7(2): 164-168 (2019). 